\title{
Identification of Fungal Species Associated with Branch Dieback of Olive and Resistance of Table Cultivars to Neofusicoccum mediterraneum and Botryosphaeria dothidea
}

Juan Moral, Departamento de Agronomía, ETSIAM, Universidad de Córdoba, Campus de Rabanales, Edif. C4, 14071 Córdoba, Spain; and Kearney Agricultural Research and Extension Center, University of California-Davis, Parlier 93648; Carlos Agustí-Brisach, Mario Pérez-Rodríguez, Carlos Xaviér, and M. Carmen Raya, Departamento de Agronomía, ETSIAM, Universidad de Córdoba, Campus de Rabanales; Ali Rhouma, Institute de l'Olivier, Mahrajène, BP208, 1082, Tunisia; and Antonio Trapero, Departamento de Agronomía, ETSIAM, Universidad de Córdoba, Campus de Rabanales

\begin{abstract}
Over two consecutive seasons, 16 olive orchards with trees exhibiting dieback symptoms on branches were surveyed in southern Spain. The six dominant fungal species recovered were characterized by means of phenotypic observations, DNA analysis (by sequencing of the internal transcribed spacer, $\beta$-tubulin, and large subunit nuclear ribosomal DNA regions), and pathogenicity tests. Additionally, three isolates collected from Tunisian olive trees showing similar dieback symptoms, one isolate of Colletotrichum godetiae, and a reference isolates of Neofusicoccum mediterraneum were included. The resistance of the 11 most important table cultivars to N. mediterraneum and Botryosphaeria dothidea, the causal agent of "escudete" (small shield) of fruit, was studied by the inoculation of branches and immature fruit, respectively. The species Cytospora pruinosa,

N. mediterraneum, Nothophoma quercina, Comoclathris incompta, and Diaporthe sp. were identified. Only $N$. mediterraneum and $C$. incompta were able to induce the typical dieback symptoms and cankers that affected the development of the plants. The species $N$. mediterraneum was the most virulent among the evaluated species, although differences in virulence among its isolates were observed. The remaining fungal species were weakly pathogenic to nonpathogenic on plants. According to resistance tests, 'Gordal Sevillana' and 'Manzanilla Cacereña' were the most susceptible to branch dieback caused by $N$. mediterraneum. Furthermore, the fruit of 'Aloreña de Atarfe' and 'Manzanilla de Sevilla' were the most susceptible to $B$. dothidea. Knowledge of the etiology and cultivar resistance of these diseases will help to establish better control measures.
\end{abstract}

Cultivated olive (Olea europaea subsp. europaea L) is the most important perennial crop in Spain. Spain leads the world in olive production, generating about $43 \%$ of the world's olive fruit. The Spanish olive industry accounts for $25 \%$ of the global acreage designated for olive production, occupying $2.5 \times 10^{6}$ ha (for both table fruit and oil). Approximately $65 \%$ of this land lies in the Andalusia region of the southern Iberian Peninsula, in itself producing $85 \%$ of the total production for Spain (Barranco et al. 2008). Global table fruit production is around $2.3 \times 10^{6}$ tons per year, $23 \%$ of which come from Spain (MAGRAMA 2016). The most important table cultivars are 'Gordal Sevillana' and 'Manzanilla de Sevilla', both comprising approximately $85 \%$ of table fruit production. In addition, other table cultivars such as 'Aloreña' and 'Morona' have a secondary importance but their fruit are appreciated for their organoleptic properties. Finally, some cultivars such as 'Hojiblanca', 'Manzanilla Cacereña', and 'Verdial de Huévar' have a twofold purpose as both table fruit and as oil, while some other cultivars such as 'Picual' are used exclusively for oil production (Rallo et al. 2005).

At the beginning of the 2000s, a serious disease showing typical dieback symptoms was observed in olive orchards in the Andalusia region, where 'Gordal Sevillana' was the most affected cultivar (Romero et al. 2005). Similar symptoms were also observed affecting other cultivars such as 'Arbequina', 'Manzanilla de Sevilla', and 'Picual'. Differences in susceptibility among cultivars to the disease are evident in the field but knowledge regarding the resistance of cultivars to twig-branch dieback is unknown. Affected trees showed an

Corresponding author: J. Moral; E-mail: jmoral@ucdavis.edu

J. Moral and C. Agustí-Brisach contributed equally to this article.

Accepted for publication 5 October 2016.

C) 2017 The American Phytopathological Society abundance of dead twigs and wilted leaves that remained attached to blighted branches, which were generally associated with the decline of entire young stems or older branches (Moral et al. 2010; Romero et al. 2005; Úrbez-Torres et al. 2013). The branches showing cankers are less tolerant to water stress and had an insufficient water and nutrient flow through both xylem and phloem vessels. Consequently, characteristic dieback symptoms such as bud mortality, leaf chlorosis, fruit rot, and twig dieback occur when water and nutrient demand exceeds the conductive capacity of the vascular tissues (ÚrbezTorres et al. 2013).

Olive fruit can be affected by numerous species of the family Botryosphaeriaceae, including species belonging to the genera Botryosphaeria and Neofusicoccum that are well known to cause cankers, dieback, and rot of mature and immature fruit (Carlucci et al. 2013; Lazzizera et al. 2008a, 2008b; Moral et al. 2008a, 2010; Úrbez-Torres et al. 2013). However, further studies may elucidate the etiology of these diseases in Spain, and the relationship between affected host tissue and pathogen species.

The species N. luteum (Pennycook \& Samuels) Crous, Slippers \& A. J. L. Phillips was described causing stem cankers and tip dieback in olive branches in New Zealand (Taylor et al. 2001), and causing leaf necrosis in Australia (Sergeeva et al. 2009). In Spain, Moral et al. (2010) observed that $N$. mediterraneum Crous, M. J. Wingf. \& A. J. L. Phillips was the prevalent species associated with branch dieback, mainly on 'Gordal Sevillana'. The Botryosphaeriaceae species Diplodia mutila (Fr.) Mont.; D. seriata De Not.; Dothiorella iberica A. J. L. Phillips, J. Luque \& A. Alves; Lasiodiplodia theobromae (Pat.) Griffon \& Maubl.; N. luteum; N. parvum; and N. vitifusiforme (Van Niekerk \& Crous) Crous, Slippers \& A. J. L. Phillips were also reported to cause branch dieback and blight, and eventual death of shoots in different olive-growing areas (Carlucci et al. 2013; Moral et al. 2010; Úrbez-Torres et al. 2013).

On olive drupes, Diplodia olivarum A. J. L. Phillips, Frisullo \& Lazzizera and D. seriata were reported causing rot on mature fruit in Italy (Lazzizera et al. 2008a) and Spain (Moral et al. 2008b), respectively. In Australia, N. luteum was also observed causing rot of mature fruit (Sergeeva et al. 2009). Conversely, because immature 
olive fruit are highly resistant to fungi, no significant pathogens have been observed causing rot on them, with the exception of Botryosphaeria dothidea (Moug.) Ces. \& De Not. (Moral et al. 2008b, 2010). This pathogen is the causal agent of Dalmatian disease of olive, which can be found in most of the Mediterranean basin (Iannotta et al. 2007; Latinović et al. 2013; Moral et al. 2010; Zachos and TzavellaKlonari 1983). B. dothidea produces a sunken, necrotic, and circular lesion (approximately $8 \mathrm{~mm}$ in diameter, never larger than $1 \mathrm{~cm}$ ) with a sharp edge delineating infected and healthy fruit tissues; this appearance is called "escudete" (or small shield) in Portuguese and Spanish. As the disease progresses, the necrotic spots expand and eventually encompass the entire fruit. Then, when the fruit matures, it falls to the ground and is mummified (Moral et al. 2010). Overall, the incidence of olive fruit showing the Dalmatian symptoms is relatively low but, frequently, it exceeds the tolerance level for the "Extra" Class standard for the olive fruit, which is usually at a 2 or $4 \%$ level, according to the Spanish Royal Decree 1230/2001 or the "Codex Alimentarius" of the FAO, respectively.

Botryosphaeriaceae asexual stage is predominant in the majority of its hosts. In olive, the sexual stage has been reported in only a few cases for B. dothidea and N. mediterraneum in California and Spain, respectively (Moral et al. 2010, 2015). Recently, Eldesouki (2013) elucidated the Dalmatian disease cycle, in which the mosquito Prolasioptera berlasiana, a predator of olive fly eggs (Bactrocera oleae), carries the $B$. dothidea spores in a mycangium (a specialized structure, like a pocket). The mosquito is attracted to ovipositor punctures on the olive surface made by the olive fly. When the mosquito deposits its own egg adjacent to the fly egg, it also inoculates the puncture with the fungus. Because the mosquito cannot penetrate intact fruit, the control of olive flies incidentally involves the control of the Dalmatian disease (Moral et al. in press). However, there is little information on the control of Dalmatian disease by the use of resistant olive cultivars. In Montenegro, Latinović et al. (2013) studied the resistance of olive cultivars infected with $B$. dothidea, demonstrating that 'Crnjaka' and 'Gloginja' (native cultivars) and 'Pendolino' and 'Cassanesse' (Italian cultivars) were highly resistant to the disease. These authors evaluated the resistance of only one Spanish cultivar, 'Manzanilla'; however, the identity of this cultivar is unclear because the name "Manzanilla" includes more than 20 cultivars, such as 'Manzanilla de Sevilla,' 'Manzanilla Cacereña,' and so on (Barranco and Rallo 2000). Even so, the resistance of a broad range of Spanish olive cultivars to $B$. dothidea and $N$. mediterraneum has not been evaluated yet in Spain.

During the last few decades, other pathogens have also been associated with olive twig-branch dieback. For example, the species Cytospora oleina Berl. and Eutypa lata (Pers.) Tul. \& C. Tul. have been associated with olive cankers and consequent branch dieback in Greece (Rumbos 1988, 1993). The latter pathogen was recently reported in California and Italy causing dieback of olive trees (Tosi and Natalini 2009; Úrbez-Torres et al. 2013). The species Comoclathris incompta (Sacc. \& Martelli) Ariyaw. \& K. D. Hyde has also been described causing branch dieback in olive in Croatia, Greece, and Italy (Ivic et al. 2010; Malathrakis 1979; Tosi and Zazzerini 1994). Recently, Phoma fungicola has been associated with branch dieback of olive trees in Tunisia (Rhouma et al. 2010; Taieb et al. 2014). In addition, several fungi, including Diaporthe viticola Nitschke; Diatrype oregonensis (Wehm.) Rappaz; D. stigma (Hoffm.) Fr.; Phaeoacremonium aleophilum W. Gams, Crous, M. J. Wingf. \& Mugnai; Phaeomoniella chlamydospora (W. Gams, Crous, M. J. Wingf. \& Mugnai) Crous \& W. Gams; Phoma sp.; Phomopsis (Sacc.) Bubák sp. (synonym Diaporthe Nitschke); Trametes versicolor (L.) Lloyd; and Schizophyllum commune Fr., have also been associated with olive branch dieback, stem canker, and twig necrosis in California (ÚrbezTorres et al. 2013). In southern Italy, N. parvum; Pleurostomophora richardsiae (Nannf.) L. Mostert, W. Gams \& Crous; six species belonging to genus Phaeoacremonium; and Pseudophaeomoniella oleicola Nigro, Antelmi \& Crous were isolated from the wood of olive trees displaying wilting and branch dieback (Carlucci et al. 2013, 2015; Crous et al. 2015). Colletotrichum spp., the causal agents of olive anthracnose, have also been implicated as responsible for leaf wilting and branch dieback symptoms (Moral et al. 2014). Although these fungi affect fruit, preliminary studies demonstrated that the toxic substances produced by Colletotrichum spp. on rotten fruit are able to incite leaf wilting and branch dieback (Moral et al. 2009). In the latter study, for example, olive plants without fruit were infected by the pathogen but did not show any disease symptoms. However, the plant inoculations were conducted by using a conidial suspension and not using the conventional mycelium plugs of the pathogen (Moral et al. 2009).

In Spain, little attention has been given to olive branch dieback or the Dalmatian disease. Nevertheless, both diseases have increasingly become concerns among growers in the main table-oliveproducing areas of the Andalusia region. Determination of the etiology, epidemiology, and control of these diseases are required; therefore, the objectives of the current study were to (i) identify on the basis of morphology and molecular phylogeny the different fungal species associated with the olive twig-branch syndrome, (ii) evaluate the pathogenicity of the different fungi associated with the olive twig-branch dieback, and (iii) evaluate the resistance of the most common table cultivars to $N$. mediterraneum and B. dothidea, the causal agents of twig-branch dieback and Dalmatian disease, respectively.

\section{Material and Methods}

Field surveys and fungal isolation. In 2009 and 2010, field surveys were conducted in orchards of 'Gordal Sevillana' and 'Picual' olive located in the Andalusian provinces of Jaén and Sevilla (Table 1). In total, 163 samples were collected from 16 olive orchards, each being 25 years old or older. Branches and twigs from olive trees showing the typical symptoms of branch dieback such as cankers, internal wood necrosis, black vascular streaking. or discolored tissues were collected. Parafilm (Parafilm, Menasha, WI) was used to seal both ends of all samples; then, samples were placed in black plastic bags and kept at $4{ }^{\circ} \mathrm{C}$ until isolations were made.

Branches and twigs were surface disinfected with $50 \%$ ethanol. The outer bark was removed with a sterile scalpel. Small pieces from the edge between healthy and affected wood tissue were plated on potato dextrose agar (PDA; Biokar-Diagnostics, Zac de Ther, France) acidified with lactic acid $(2.5 \mathrm{ml}$ at $25 \%$ [vol/vol] per liter of medium). Petri dishes were incubated at 23 to $27^{\circ} \mathrm{C}$ under a 12 -h photoperiod of cool fluorescent light $\left(350 \mu \mathrm{mol} \mathrm{m}^{-2} \mathrm{~s}^{-1}\right)$ until colonies were large enough to be examined. To obtain pure cultures, mycelial fragments from the margin of the fungal colonies were transferred to acidified PDA and incubated as described before. Several isolates collected in affected 'Meski' orchards from Tunisia were also included in this study (Table 1). Fungal species were isolated for further study from 10 olive trees from three different orchards. The studied isolates are maintained in the collection of the Departamento de Agronomía, Universidad de Córdoba, Spain.

Morphological characterization. Based on morphological characteristics, fungal species were first identified to genus. Pycnidial and conidial characteristics such as shape, size, color, and presence or absence of septa were recorded from the colonies developed in vitro. For morphological identification, single conidial cultures were derived using the serial dilution method (Dhingra and Sinclair 1995) and grown on PDA for up to 2 weeks at $25 \pm 2{ }^{\circ} \mathrm{C}$ with a 12-h photoperiod of cool fluorescent light $\left(350 \mu \mathrm{mol} \mathrm{m}^{-2} \mathrm{~s}^{-1}\right)$. To induce pycnidia development, the same isolates were cultured on sterile 'Gordal Sevillana' leaves, which were previously autoclaved at $120^{\circ} \mathrm{C}$ for $20 \mathrm{~min}$, and placed into petri dishes containing $5 \mathrm{ml}$ of molten PDA (Moral et al. 2009). Petri dishes were incubated as described above for 10 days. Three petri dishes per isolate were used. The experiment was performed twice.

Fungal structures were measured using a Nikon Eclipse 80i microscope and images were captured using the NIS-Element software (Nikon Corp., Tokyo). Conidial masses were observed from pycnidia mounted in water. Color (using a color scale) (Kornerup and Wanscher 1963), morphology, and diameter of pycnidia from these isolates were recorded. For conidial measurements, mycelial plugs were removed from the petri dishes, placed on slides with a drop of $0.005 \%$ acid fuchsine in lactoglycerol (1:1:1 lactic acid, glycerol, and water), 
and covered. For each isolate, 30 measurements were obtained for each structure. The averages of length and width and the length/width relation were calculated. Characteristics of conidia (color, shape, and septation) and mycelia (texture, density, color, and zonation) were also recorded after 14 days of incubation at 23 to $27^{\circ} \mathrm{C}$ in the dark (Barnett and Hunter 1998; Sutton 1980).

DNA extraction, amplification, and phylogenetic analysis. One to three isolates were selected based on their morphology as representative of each of three fungal taxa, and their identification was confirmed by using molecular techniques (Table 1). Fungal isolates were grown on PDA for 14 days. FastDNA Kit (BIO 101, Inc., Vista, CA) was used to extract total genomic DNA. The nuclear ribosomal DNA (nrDNA) repeats, including the internal transcribed spacer (ITS) 1, 5.8S ribosomal RNA (rRNA), ITS5, and portions of the genes encoding both small and large subunit rRNA, were amplified using primers ITS1 and ITS4 (White et al. 1990). The partial large subunit nrDNA (LSU) was amplified with the primer pair LR0R and LR7 (Rehner and Samuels 1994; Vilgalys and Hester 1990). Oligonucleotide primers $\mathrm{Bt} 2 \mathrm{a}$ and $\mathrm{Bt} 2 \mathrm{~b}$ were used to amplify a portion of the $\beta$-tubulin (BT) gene (Glass and Donaldson 1995). Finally, amplification of part of the translation elongation factor 1- $\alpha(\mathrm{EF})$ gene was done with the primers EF1-728F and EF1-986R (Carbone et al. 1999). The polymerase chain reaction (PCR) of BT, EF, ITS, and LSU was conducted according to previous studies (Chen et al. 2015; Lazzizera et al. 2008b; Moral et al. 2010). The PCR products were purified with an Ultra Clean PCR Clean-Up Kit (MO BIO Laboratories, Inc., Solana Beach, CA). The resulting amplicons were sequenced in both directions using an automated sequencer by the University of Córdoba sequencing facility (ABI Prism 3130XL Genetic Analyzer; Applied Biosystems, Foster City, CA). The nucleotide sequences were read and edited with FinchTV 1·4·0. Sequences were assembled and edited to resolve ambiguities using the program SeqMan (DNASTAR Lasergene, Madison, WI), and consensus sequences for all isolates were compiled into a single file (Fasta format).

Phylogenetic analysis with all isolates was first conducted with the BT, EF, ITS, and LSU data sets individually, and the four topologies were compared. A partition homogeneity test was performed to determine whether BT, EF, ITS, and LSU data sets could be combined. The combined alignment of the two loci BT and ITS was first analyzed for inferring the phylogeny of the isolates. Phylogenetic analysis on the LSU single-locus alignment was used to elucidate the organismal phylogeny. GenBank sequences (Table 1) from different species of Neofusicoccum, Colletotrichum, Cytospora, Phoma-like, or Diaporthe were selected based on their high similarity with our query sequences using MegaBLAST. Ganoderma resinaceum (GR145) and Coltriccia cinnamomea (Dai 2464) were used as the outgroups of the combined alignment of the two loci BT and ITS, and the LSU single-locus alignment. These were added to the sequences obtained and aligned using CLUSTALW v. 2.0.11 (Larkin et al. 2007). The genetic distances were calculated using the Kimura two-parameter model. For phylogenetic inference, the neighbor-joining (NJ) method was used (Saitou and Nei 1987). The NJ tree and the statistical confidence of a particular group of sequences in the tree, evaluated by bootstrap (BS) test (2,000 pseudoreplicates), were performed using the computer program MEGA 6 (Tamura et al. 2013). Sequences derived in this study were lodged at GenBank. GenBank accession numbers of the strains collected during this study are listed in Table 1.

Pathogenicity tests. One representative isolate of each identified species was inoculated toward to determine their pathogenicity capacity. In addition, one Colletotrichum godetiae isolate (CH-21), which belongs to the C. acutatum species complex and is the dominant species in the Andalusian population of the pathogen (Moral et al. 2014), was selected to determine pathogenicity on olive detached branches or potted plants (Table 1).

Pathogenicity on detached branches. In March 2010, branch segments (14 to $18 \mathrm{~cm}$ long and 1.0 to $1.5 \mathrm{~cm}$ in diameter) were collected from 'Gordal Sevillana' trees from The Olive Cultivars Garden orchard that belongs to the Andalusian Institute for Research and Formation in Agriculture and Fishery (IFAPA in Spanish) and is located in Mengíbar (Jaén province, Andalusia region). The branch segments were sealed at both ends with Parafilm to reduce desiccation, and bark surfaces were sterilized with $70 \%$ ethanol at the point of inoculation, situated in the middle of each branch. In order to remove the outer bark yet leave the inner bark intact, 10-mm-diameter holes were made in the bark using a cork borer. In the cavities, a 10-mmdiameter mycelium plug of each isolate was inserted such that the inoculum was placed in direct contact with vascular tissues, as described by Moral et al. (2010); then, the inoculated area was wrapped with Parafilm. In total, 11 representative isolates belonging to six species were individually tested using five replicate branches per isolate. The experiment was repeated three times and five branches were treated with acidified PDA as control. Inoculated and control branches were then incubated in humid chambers (plastic containers, 30 by 23 by $6 \mathrm{~cm}$, with $100 \%$ relative humidity [RH] obtained by adding $300 \mathrm{ml}$ of water) at room temperature $\left(26\right.$ to $\left.33^{\circ} \mathrm{C}\right)$ under continuous cool fluorescent lights $\left(350 \mu \mathrm{mol} \mathrm{m} \mathrm{m}^{-2} \mathrm{~s}^{-1}\right)$ for 30 days. Humid chambers were placed inside at room temperature in a completely randomized design. For each branch, evaluation of the lesion length and the length of the colonized bark surface bearing pycnidia, and calculation of the relative (percent) affected length of each branch were obtained according to Moral et al. (2010). Small wood fragments that form the margin of the affected area of each inoculated branch were plated on acidified PDA to isolate the pathogens.

Pathogenicity on potted plants. Five-year-old potted 'Gordal Sevillana' plants were obtained from a commercial nursery. Each plant was inoculated with mycelium plugs as described above for detached branches. The same 11 isolates were inoculated using three replicate plants per isolate and four branches per plant. After inoculation, plants were placed in a greenhouse at 25 to $30^{\circ} \mathrm{C}$ in a completely randomized design and were irrigated as needed. The area around the experiment was abundantly irrigated to increase the RH. Lesion length and percentage of dead branches were assessed 90 days after inoculation. The pathogens were isolated from the olive branches as described above. The experiment was repeated three times and five branches from the same plant were treated with acidified PDA as control in each replicate of the experiment.

Evaluation of cultivar resistance. To evaluate the resistance of different table cultivars to $N$. mediterraneum, which was the most virulent species of the previous experiments, branches and 5-yearold plants of 10 table cultivars were inoculated using the reference isolate $N$. mediterraneum BOO071. In the same way, the resistance of cultivars to $B$. dothidea was evaluated using the reference isolate B. dothidea BOO046 (Moral et al. 2010).

Branch inoculation with N. mediterraneum. In March 2010, branch segments (14 to $18 \mathrm{~cm}$ long and 1.0 to $1.5 \mathrm{~cm}$ in diameter) were cut from 10 table olive cultivars growing at The Cultivar Garden orchard (Table 2). Sampling and inoculation were conducted as described above. Ten branches per cultivar were inoculated and the experiment was conducted three times. Likewise, another 10 branches per replicate were treated with acidified PDA as control. In total, 270 branches were inoculated with $N$. mediterraneum and 90 branches were used as control. All of the branches were incubated in humid chambers as described above. Evaluation of lesion length and the length of the colonized bark surface bearing pycnidia, and calculation of the relative (percent) affected length of each branch were obtained according to Moral et al. (2010). The pathogen was reisolated from the branches as described above.

Plant inoculation with N. mediterraneum. Five-year-old potted plants of seven table cultivars were obtained from a commercial nursery in Cordoba province from Andalusia (Table 2). Each plant was inoculated with $N$. mediterraneum using mycelial plugs as described above. Three replicate plants and four branches of each one per cultivar were inoculated. Five branches from the same plant were treated with acidified PDA as control in each replicate (plant) of the experiment. Inoculated plants were then incubated in a greenhouse from 25 to $30^{\circ} \mathrm{C}$ in a completely randomized design, and irrigated abundantly to increase the $\mathrm{RH}$. The percentage of dead branches and the lesion length of inoculated branches were assessed 90 days after inoculation. The experiment was repeated four times. The pathogen was isolated from the branches as described above. 
Fruit inoculation with B. dothidea. In September 2010, immature fruit of 10 table cultivars were collected from The Cultivar Garden orchard (Table 2). Fruit were washed, disinfested, and inoculated according to Moral et al. (2010). Inoculated and control fruit (PDA plugs without mycelia) were incubated in humid chambers as described above. Disease severity was assessed every 2 weeks for 2 months using a 0 -to- 5 rating scale previously described by Moral et al. (2008a). Disease severity index (DSI) was calculated according to the formula DSI $=\left(\sum n i \times i\right) / N$, where $i$ represents severity (0 to 5), $n i$ is the number of fruit with the severity of $i$, and $N$ is the total number of fruit (Moral et al. 2008a). The area under the disease progress curve (AUDPC) was calculated by trapezoidal integration of DSI values over time. There were three replicates (humid chambers) per treatment and 30 fruit per replicate. Treatments were arranged in a completely randomized design.

Statistical analysis. Analysis of variance (ANOVA) and means comparison tests were conducted to determine the differences in virulence among isolates and in resistance among cultivars. For the different analyses conducted, dependent variables were lesion length to evaluate differences in virulence among isolates; lesion length and pycnidia colonization or dead branches (percent) to evaluate differences in resistance among cultivars by using detached branches or potted plants, respectively; and AUDPC to evaluate differences in resistance among cultivars by using detached fruit. When ANOVA showed significant differences, the treatment means were compared according to Tukey's honestly significant difference test at $P=0.05$. The nonpathogenic isolates were excluded from the statistical analysis. The data were logarithmically transformed to meet the homogeneity of the variances or normality. Because the data of cultivar resistance to $N$. mediterraneum did not show homogeneity of variances, even with the logarithmic transformation, they were analyzed using the Kruskal-Wallis nonparametric test and the cultivars were compared according to Dunn's test at $P=0.05$. Linear regression was used to study the relationship between dependent variables of this study. In addition, we studied the relation between fruit resistance to B. dothidea and the susceptibility to fruit rot caused by Colletotrichum spp. (Moral et al. 2014). All the data were analyzed by using Statistix 10 (Analytical software 2013).

\section{Results}

Collection of fungal isolates. In total, 120 fungal isolates from affected olive trees showing twig-branch dieback were recovered in Spanish olive orchards. Overall, olive twig death was usually associated with cankered stems. Among the collected isolates, five fungal groups were clearly differentiated, the most frequent being Botryosphaeriaceae species (mainly $N$. mediterraneum), followed by Cytospora spp., a Phoma-like species (two subgroups), and Diaporthe spp. Representative isolates from each of the five fungal groups were selected for further studies. In addition, a fungal group of isolates that were frequently isolated from affected orchards in Tunisia was included.

Morphological characterization. All studied isolates showed mycelial growth and sporulation within 14 days of incubation on olive leaves, except one Phoma-like isolate, $\mathrm{CH}-12$, which showed very poor mycelial growth but developed some pycnidia around the original mycelium plug. Based on their appearance in culture, the isolates were again assigned to five main fungal groups (Table 3). The first group comprised a Botryosphaeriaceae species with a Neofusicoccum anamorph (isolates BOO071 and CH-06); this species was characterized by floccose to felted aerial mycelium showing colors that varied from light to olive green on acidified PDA. Conidia were hyaline, aseptate, and fusiform. Pycnidia were dark, ostiolate, globose, and erumpent. Two groups (group 2 and 3) were clearly differentiated, belonging to Phoma-like isolates. Group 2 (isolates $\mathrm{CH}-04$ and $\mathrm{CH}-16$ ) was characterized by brown to yellowish mycelium with a regular margin. Conidia were dark, ellipsoid or ovoid, slightly flattened, and thin-walled. Pycnidia were irregular, branched, wooded, velvety, and sprawled. Group 3 (isolates $\mathrm{CH}-14$ and $\mathrm{CH}-15$ ) showed flat, fine, medium density to very dense mycelium; the color varied from white to pink, or green to yellow, with a regular colony margin. Conidia were hyaline, aseptate, and oblong. Pycnidia were dark, ostiolate, and globose. A fourth group included a Diaporthe sp. that was characterized by having white, cottony, slow-growing, raised mycelium with a regular colony margin. In this fourth group, two types of hyaline conidia were observed: oblong, slightly fusiform, and ligulated conidia $(\alpha)$; and filiform and curved conidia $(\beta)$. Pycnidia were dark, ostiolate, globose, erumpent, and velvety. Finally, Cytospora isolates formed a fifth group characterized by white, flat, felty, texture uniform mycelium with an irregular colony margin. Conidia were hyaline, aseptate, and with an alantoide form. Pycnidia were dark, erumpent, ostiolate, tuberculate, globous, and velvet. (Tables 3 and 4; Fig. 1).

Molecular characterization. To confirm the identification based on morphology, BT, EF, ITS, and LSU regions were obtained for all isolates studied. The combined alignment of BT and ITS included 18 taxa (including the outgroup G. resinaceum) (Fig. 2). In this phylogenetic tree, combined sequences of the genera Colletotrichum (isolate $\mathrm{CH}-21$ ), Cytospora (isolate $\mathrm{CH}-13$ ), Diaporthe (isolates $\mathrm{CH}-01$ and $\mathrm{CH}-03$ ), Neofusicoccum (isolates $\mathrm{CH}-06$ and BOO071), and Nothophoma (isolates $\mathrm{CH}-4, \mathrm{CH}-14$, and $\mathrm{CH}-15$ ) formed five wellsupported clades, in which BS support ranged from 94 to $100 \%$. Each clade incorporated one representative isolate of $C$. godetiae (CBS 127561), Cytospora pruinosa (Fr.) Sacc. (CBS 118555), Diaporthe sp. (UCR1395), N. mediterraneum (UCD720SJ) and Nothophoma quercina (Syd. \& P. Syd.) Q. Chen \& L. Cai (CBS 633.92) for Colletotrichum, Cytospora, Diaporthe, Neofusicoccum, and Nothophoma clades, respectively. However, the isolates $\mathrm{CH}-12$ and $\mathrm{CH}-16$ clustered in a subclade close to Leptosphaeria biglobosa Shoemaker \& H. Brun (CBS 532.66) with a low BS value (BS = $74 \%$ ) and were hypothesized as a Phoma-like species. Subsequently, phylogenetic analysis on the LSU single-locus alignment was analyzed for the elucidation of the organismal phylogeny of the doubtful isolates (Fig. 3). This alignment was successful in identifying all of the isolates. The isolates $\mathrm{CH}-01$ and $\mathrm{CH}-03$ were grouped together in a clade $(\mathrm{BS}=$ 99\%) with a representative isolate of Diaporthe sp. (PHAg); the isolate $\mathrm{CH}-13$ clustered $(\mathrm{BS}=100 \%)$ with a representative isolate of C. pruinosa (CBS119207); and the isolates $\mathrm{CH}-12$ and $\mathrm{CH}-16$ clustered (BS $=93$ and $100 \%$, respectively) with a representative isolate of Comoclathris incompta (CBS 467.76). The rest of the isolates formed the same clades as those observed in the combined alignment of BT and ITS. Finally, sequences of EF and its single-locus alignment were not helpful in identifying our Phoma-like isolates.

Pathogenicity tests. Pathogenicity on detached branches. Necrotic lesions on 'Gordal Sevillana' branches were observed 2 weeks after inoculation. In general, vascular tissues showed sunken and sectorial necrotic lesions in the affected wood. Eventually, pathogens belonging to the Cytospora, Phoma-like, or Diaporthe genera produced cankers on the bark of the inoculated branches. Only the two N. mediterraneum isolates (BOO071 and $\mathrm{CH}-06$ ), a Cytospora sp. isolate (CH-13), and a $C$. incompta isolate $(\mathrm{CH}-16)$ caused visible lesions on detached branches. Both $N$. mediterraneum isolates were the most virulent $(P<0.05)$, causing an average length of necrosis of $15.93 \pm 3.04$ and $13.51 \pm 5.96 \mathrm{~cm}$, respectively (Fig. 4). The remaining fungal species (Colletotrichum godetiae, Phoma-like sp., and Diaporthe sp.) did not cause lesions on inoculated branches. Further, no lesions were observed in control branches. The species $N$. mediterraneum, Cytospora pruinosa, and Comoclathris incompta were isolated from affected tissues, and Colletotrichum godetiae, Diaporthe sp., and Nothophoma quercina were isolated from asymptomatic branches. A significant and positive linear correlation $(P<0.001$, $R^{2}=0.724$ ) was observed between the length of necrosis and pycnidia production, the bark surface inoculated with $N$. mediterraneum isolate BOO071 being that producing the highest number of pycnidia of the pathogen (data not shown).

Pathogenicity on potted plants. The first symptoms were observed 30 days after inoculation with mycelium plugs on the xylem tissues of Gordal Sevillana. Symptoms - mainly vascular necrotic lesions-were similar to those observed in detached branches. Only the $N$. mediterraneum isolates BOO071 and $\mathrm{CH}-06$ and the C. incompta isolate $\mathrm{CH}-06$ were able to induce the typical dieback 
symptoms and cankers that affected the development of the plants, where the BOO071 isolate was the most virulent (Fig. 4). The remaining fungal species (C. godetiae, $C$. pruinosa, Diaporthe sp., and $N$. quercina) did not cause any lesions on inoculated plants as with the control branches. The species $N$. mediterraneum and $C$. incompta were consistently isolated from affected tissues while C. godetiae, C. pruinosa, Diaporthe sp., and N. quercina were isolated distantly from points away from the inoculation point on asymptomatic branches.

Evaluation of cultivar resistance. Branch inoculation with N. mediterraneum. Olive branches of the nine inoculated cultivars showed vascular necrotic tissues after 2 weeks of inoculation. Symptoms observed were the same as those described above. According to the lesion on detached and inoculated branches, 'Gordal Sevillana' was significantly $(P<0.05)$ the most susceptible to the pathogen (necrosis length $15.72 \pm 4.62 \mathrm{~cm}$ ), followed by 'Santa Caterina' and 'San Agostino', which did not show significant differences $(P>$ 0.05 ) among them. Conversely, 'Manzanilla Cacereña' was the least susceptible cultivar (necrosis length $6.19 \pm 2.11 \mathrm{~cm}$ ), followed by 'Verdial de Huévar' and 'Morona', which did not show significant $(P>0.05)$ differences among them (Table 2). For all of the cultivars, a weak but significant negative correlation $\left(R^{2}=0.190, P=0.0001\right)$ between branch diameter and length of necrosis was observed, showing that branch susceptibility increased when the diameter of branches decreased. Finally, a significant positive linear correlation $\left(R^{2}=\right.$ $0.1359, P<0.001$ ) was observed between the length of necrosis and pycnidia production (data not shown), the bark surface of 'San Agostino' being the most occupied by pycnidia.

Plant inoculation with $\mathrm{N}$. mediterraneum. Olive plants showed the first symptoms at 14 days after inoculation, while the first dead branches were observed at 8 weeks. In the potted plant trials, 'Manzanilla Cacereña' and 'Gordal Sevillana' showed a high percentage of dead branches, 83.33 and $62.50 \%$, respectively, whereas 'Aloreña de Atarfe', 'Hojiblanca', and 'Verdial de Huévar' did not produce any dead branches (Table 2). According to necrosis length, 'Manzanilla Cacereña' and 'Gordal Sevillana' were also the most susceptible to the pathogen (necrosis lengths of $10.6 \pm 3.27$ and $10.38 \pm 2.52 \mathrm{~cm}$, respectively) without significant differences between them. The remaining cultivars ('Aloreña de Atarfe', 'Hojiblanca', 'Manzanilla de Sevilla', 'Morona', and 'Verdial de Huévar') were significantly less susceptible (necrotic lesions of 3.06 to $5.25 \mathrm{~cm}$ ) than the previous two cultivars and formed a homogeneous group $(P>0.05)$. When we studied the relationship between the percentage of dead branches of the different cultivars and their canker lengths (from detached branches and branches in vivo), the percentage of dead branches was observed to be significantly $\left(R^{2}=0.965, P<0.001\right)$ related to the canker lengths of inoculated potted plants, whereas the relationship was not significant $(P=0.8740)$ when detached branches were used.

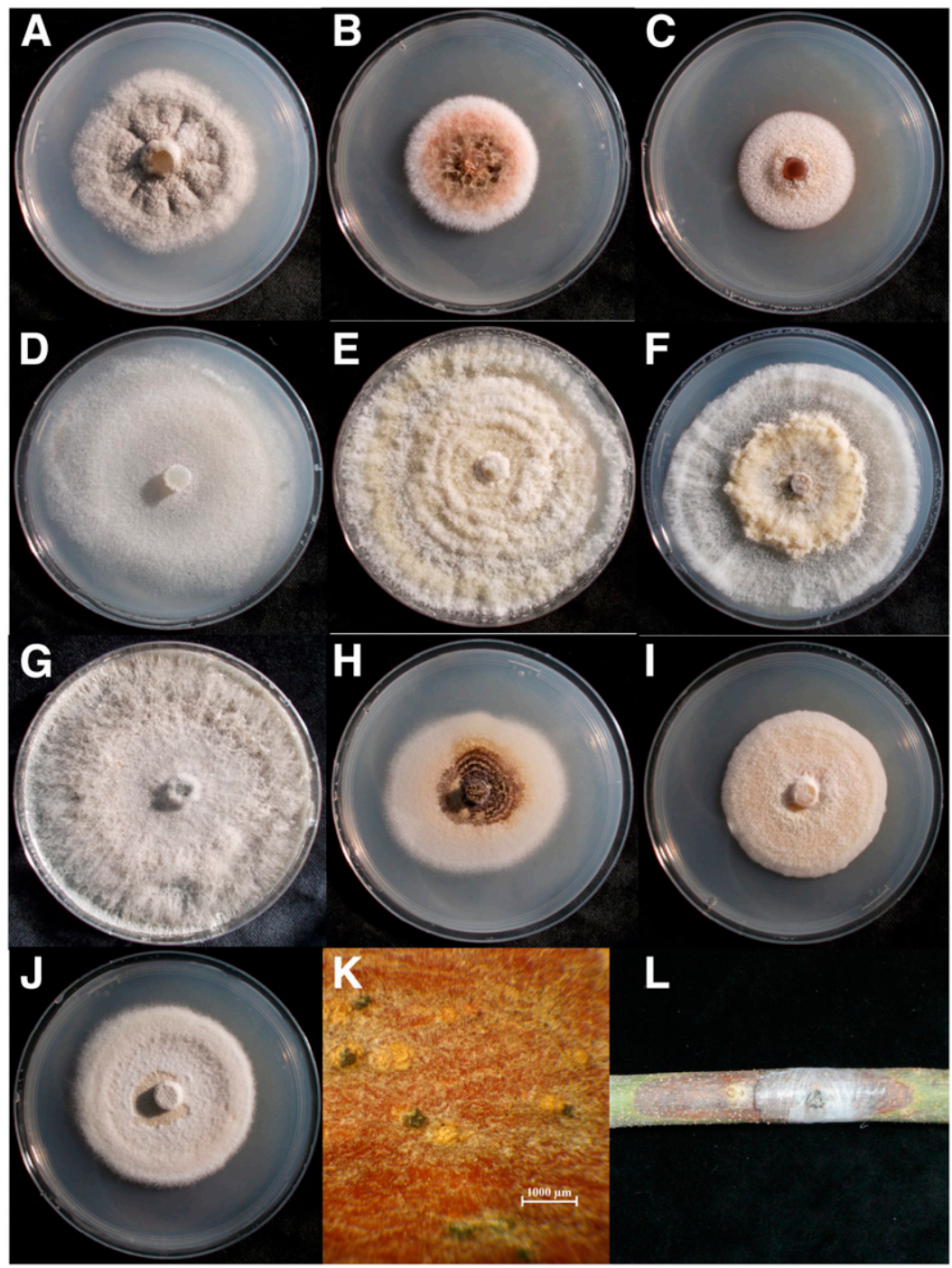

Fig. 1. Two-week-old colonies on potato dextrose agar of the different fungal species isolated from olive trees in Spain and Tunisia. A, Colletotrichum godetiae isolate $\mathrm{CH}-21 ; \mathbf{B}$ and $\mathbf{C}$, Comoclathris incompta isolates $\mathbf{C H}-12$ and $\mathrm{CH}-16$, respectively; $\mathbf{D}$, Cytospora pruinosa isolate $\mathbf{C H}-13$; $\mathbf{E}$ and $\mathbf{F}$, Diaporthe sp. isolates $\mathbf{C H}-01$ and $\mathbf{C H}-03$, respectively; $\mathbf{G}$, Neofusicoccum mediterraneum isolate $\mathrm{CH}-06$; $\mathbf{H}$ to J, Nothophoma quercina isolates $\mathrm{CH}-04, \mathrm{CH}-14$, and $\mathrm{CH}-15$, respectively; $\mathrm{K}$, Pycnidia of $\mathrm{N}$. mediterraneum isolate $\mathrm{CH}-06$ embedded in the bark of a young olive stem; L, Canker lesion caused by N. mediterraneum isolate CH-06 on olive branch from San Agostino olive. 
Fruit inoculation with $\mathrm{B}$. dothidea. When immature olive fruit were inoculated with $B$. dothidea, the first symptoms were observed at 21 days after inoculation. These were small, depressed, necrotic lesions surrounding the inoculation point that advanced until they covered the entire surface of the fruit. 'Hojiblanca', 'Manzanilla de Sevilla', and 'Morona' olive fruit were the most resistant to $B$. dothidea, although there was an extensive overlap for the AUDPC showed by the fruit of the different cultivars (Table 2). The resistance to $B$. dothidea was not correlated $(P=$ 0.6968 ) with the resistance to fruit rot caused by $C$. godetiae.

\section{Discussion}

Six fungal species belonging to six different genera were isolated from olive plants showing branch dieback symptoms in Spain and Tunisia. Affected trees showed defoliation or leaf wilting in young twigs and darker, sunken areas along affected branches, which revealed perennial cankers under the bark. Cankered zones presented a well-defined dark line of demarcation between infected and healthy tissues. Dieback diseases characterized by perennial cankers affecting branches and trunks have been studied in many different perennial hosts worldwide, including olive (Moral et al. 2010; Úrbez-Torres et al. 2013). The current work elucidates the etiology of olive branch dieback in Spain, with a special emphasis on the pathogenicity of associated fungi. Moreover, the resistance of the main table cultivars against the main causal agents of the disease has also been evaluated.

Morphological characteristics (conidial and mycelial) were useful to separate the isolates into four different groups (Botryosphaeriaceae, Cytospora, Phoma-like, and Phomopsis), in agreement with those described for each genus (Chen et al. 2015; Liu et al. 2015; Phillips et al. 2013; van Niekerk et al. 2004). Nevertheless, taxa of Phoma-like species are morphologically difficult to distinguish. This is also true for Ascochyta spp. Both of these genera have, in the past, been linked to Didymella sexual morphs. Recently, Chen et al. (2015) clarified the generic delimitation in the family Didymellaceae by combining multilocus phylogenetic analyses using ITS, LSU, the RNA polymerase II second largest subunit (rpb2) gene, partial gene regions of BT (tub2), and morphological observations. LSU, in particular, has been described as one of the most helpful regions to identify

Table 1. Fungal isolates from olive trees located in Spain and Tunisia, and sequences from GenBank used in this study

\begin{tabular}{|c|c|c|c|c|c|c|c|c|}
\hline \multirow[b]{2}{*}{ Species } & \multirow[b]{2}{*}{ Isolate $^{\mathrm{z}}$} & \multirow[b]{2}{*}{ Host, cultivar } & \multirow[b]{2}{*}{ Symptoms } & \multirow[b]{2}{*}{ Collector } & \multirow[b]{2}{*}{ Origin } & \multicolumn{3}{|c|}{ GenBank Accession number ${ }^{y}$} \\
\hline & & & & & & BT & ITS & LSU \\
\hline $\begin{array}{l}\text { Botryosphaeria } \\
\text { dothidea }\end{array}$ & BOO046 & $\begin{array}{c}\text { Olea europaea } \\
\text { Santa Caterina }\end{array}$ & $\begin{array}{c}\text { Dalmatian } \\
\text { disease }\end{array}$ & J. Moral & $\begin{array}{l}\text { Mengibar, Jaen, } \\
\text { Andalusia, Spain }\end{array}$ & GU292738 & GU292626 & $\mathrm{n} / \mathrm{a}$ \\
\hline \multirow[t]{2}{*}{$\begin{array}{l}\text { Colletotrichum } \\
\text { godetiae }\end{array}$} & $\mathrm{CH}-21$ & $\begin{array}{l}\text { O. europaea } \\
\text { Gordal Sevillana }\end{array}$ & Soapy fruit & A. Trapero & $\begin{array}{l}\text { Palomera, } \\
\text { Cordoba, } \\
\text { Andalusia, Spain }\end{array}$ & KU973701 & KU973719 & KU973721 \\
\hline & CBS 127561 & Ugni molinae & $\begin{array}{l}\text { Twig, tip } \\
\text { necrosis }\end{array}$ & U. Damm & $\begin{array}{l}\text { Chile, South } \\
\text { America }\end{array}$ & JQ950093 & JQ948442 & $\mathrm{n} / \mathrm{a}$ \\
\hline $\begin{array}{l}\text { Coltriccia } \\
\text { cinnamomea }\end{array}$ & Dai 2464 & $\ldots$ & $\ldots$ & $\begin{array}{l}\text { T. Wagner and } \\
\text { M. Fischer }\end{array}$ & Finland & $\mathrm{n} / \mathrm{a}$ & $-n / a$ & AF311003 \\
\hline \multirow[t]{3}{*}{$\begin{array}{l}\text { Comoclathris } \\
\text { incompta }\end{array}$} & $\mathrm{CH}-12$ & $\begin{array}{l}\text { O. europaea } \\
\text { Picual }\end{array}$ & Branch canker & J. Moral & $\begin{array}{l}\text { Jaen, Jaen, } \\
\text { Andalusia, Spain }\end{array}$ & KU973707 & KU973715 & KU973728 \\
\hline & $\mathrm{CH}-16$ & $\begin{array}{l}\text { O. europaea } \\
\text { Meski }\end{array}$ & Branch canker & A. Rhouma & Tunisia & KU973708 & KU973716 & KU973729 \\
\hline & CBS 467.76 & O. europaea & $\cdots$ & M. M. Averskamp & Greece & $\mathrm{n} / \mathrm{a}$ & $\mathrm{n} / \mathrm{a}$ & GU238087 \\
\hline \multirow[t]{3}{*}{$\begin{array}{r}\text { Cytospora } \\
\text { pruinosa }\end{array}$} & $\mathrm{CH}-13$ & $\begin{array}{l}\text { O. europaea } \\
\text { Gordal Sevillana }\end{array}$ & Branch canker & J. Moral & $\begin{array}{l}\text { Mengibar, Jaen, } \\
\text { Andalusia, Spain }\end{array}$ & KU973702 & KU973711 & KU973722 \\
\hline & CBS 118555 & $\begin{array}{l}\text { O. europaea } \\
\text { africana }\end{array}$ & Branch canker & Y. Li Wang & South Africa & KM034893 & DQ243790 & $\mathrm{n} / \mathrm{a}$ \\
\hline & CBS 119207 & $\ldots$ & $\ldots$ & J. Z. Groenewald & $\ldots$ & $\mathrm{n} / \mathrm{a}$ & $\mathrm{n} / \mathrm{a}$ & EU552121 \\
\hline \multirow[t]{4}{*}{ Diaporthe sp. } & $\mathrm{CH}-01$ & $\begin{array}{l}\text { O. europaea } \\
\text { Gordal Sevillana }\end{array}$ & Branch canker & A. Trapero & $\begin{array}{l}\text { Sevilla, Sevilla, } \\
\text { Andalusia, Spain }\end{array}$ & KU973709 & KU973717 & KU973730 \\
\hline & $\mathrm{CH}-03$ & $\begin{array}{l}\text { O. europaea } \\
\text { Gordal Sevillana }\end{array}$ & Branch canker & $\begin{array}{l}\text { M. Pérez- } \\
\text { Rodríguez }\end{array}$ & $\begin{array}{l}\text { Sevilla, Sevilla, } \\
\text { Andalusia, Spain }\end{array}$ & KU973710 & KU973718 & KU973731 \\
\hline & UCR1395 & $\begin{array}{l}\text { Persea americana } \\
\text { Hass }\end{array}$ & Fruit & M. Twizeyimana & San Diego, CA & JX898989 & JX869042 & $\mathrm{n} / \mathrm{a}$ \\
\hline & PHAg & $\ldots$ & Branch canker & M. Pilloti & Rome & $\mathrm{n} / \mathrm{a}$ & AY620999 & AY621002 \\
\hline $\begin{array}{l}\text { Ganoderma } \\
\text { resinaceum }\end{array}$ & GR145 & $\cdots$ & $\ldots$ & C. L. Su & Shanghai, China & DQ288101 & KC311374 & $\mathrm{n} / \mathrm{a}$ \\
\hline $\begin{array}{l}\text { Leptosphaeria } \\
\text { biglobosa }\end{array}$ & CBS 532.66 & Brassica sp. & $\ldots$ & $\ldots$ & The Netherlands & KT389840 & KT389541 & KT389759 \\
\hline \multirow[t]{3}{*}{$\begin{array}{l}\text { Neofusicoccum } \\
\text { mediterraneum }\end{array}$} & $\mathrm{CH}-06$ & $\begin{array}{l}\text { O. europaea } \\
\text { Gordal Sevillana }\end{array}$ & Branch canker & J. Moral & $\begin{array}{l}\text { Sevilla, Sevilla, } \\
\text { Andalusia, Spain }\end{array}$ & KU973703 & KU973712 & KU973723 \\
\hline & BOO071 & $\begin{array}{l}\text { O. europaea } \\
\text { Gordal Sevillana }\end{array}$ & Branch canker & A. Trapero & $\begin{array}{l}\text { Arahal, Sevilla, } \\
\text { Andalusia, Spain }\end{array}$ & GU292757 & GU292645 & KU973724 \\
\hline & $\begin{array}{l}\text { UCD720SJ } \\
\text { CBS 268.80 }\end{array}$ & $\begin{array}{c}\text { Vitis vinifera } \\
\ldots\end{array}$ & $\begin{array}{c}\text { Branch canker } \\
\ldots\end{array}$ & $\begin{array}{c}\text { J. R. Úrbez-Torres } \\
\ldots\end{array}$ & California & $\begin{array}{l}\text { GU799475 } \\
\text { n/a }\end{array}$ & $\begin{array}{l}\text { GU799452 } \\
\mathrm{n} / \mathrm{a}\end{array}$ & $\begin{array}{l}\mathrm{n} / \mathrm{a} \\
\text { AY004336 }\end{array}$ \\
\hline \multirow[t]{4}{*}{$\begin{array}{l}\text { Nothophoma } \\
\text { quercina }\end{array}$} & $\mathrm{CH}-04$ & $\begin{array}{l}\text { O. europaea } \\
\text { Gordal Sevillana }\end{array}$ & Branch canker & $\begin{array}{l}\text { M. Pérez- } \\
\text { Rodríguez }\end{array}$ & $\begin{array}{l}\text { Sevilla, Sevilla, } \\
\text { Andalusia, Spain }\end{array}$ & KU973704 & KU973713 & KU973725 \\
\hline & $\mathrm{CH}-14$ & $\begin{array}{l}\text { O. europaea } \\
\text { Meski }\end{array}$ & Branch canker & A. Rhouma & Tunisia & KU973705 & KU973714 & KU973726 \\
\hline & $\mathrm{CH}-15$ & $\begin{array}{l}\text { O. europaea } \\
\text { Meski }\end{array}$ & Branch canker & A. Rhouma & Tunisia & KU973706 & KU973720 & KU973727 \\
\hline & CBS 633.92 & $\begin{array}{l}\text { Microsphaera } \\
\text { alphitoides, } \\
\text { Quercus sp. }\end{array}$ & $\ldots$ & $\ldots$ & Ukraine & GU237609 & GU237900 & EU754127 \\
\hline
\end{tabular}

${ }^{\mathrm{y}} \mathrm{BT}=\beta$-tubulin, ITS $=$ internal transcribed spacer, LSU $=$ large subunit ribosomal RNA, and $\mathrm{n} / \mathrm{a}=$ not available at the time of this publication.

${ }^{\mathrm{z}} \mathrm{CBS}=$ Centraalbureau voor Schimmecultures, Utrech, The Netherlands; UCD = University California-Davis; and UCR = University California-Riverside. Sequences from GenBank used in the phylogenetic analysis are indicated in bold. 
species belonging to the Didymellaceae family. Here, the BT, ITS, and LSU regions were needed to identify the species of each genus, LSU being especially helpful to identify Phoma-like spp. Conversely, sequences of EF were unhelpful for identification. The ITS and EF combined phylogenetic analysis was useful in describing the diversity of species that affect olive trees in Spain and Tunisia, confirming the five described groups based on morphology.

Concerning the Botryosphaeriaceae group, only one species, $N$. mediterraneum, was recovered, the prevalent pathogen in this work. The current study corroborates the presence of this species in lignified tissues of olive trees in Spain, suggested as the main causal agent of the disease (Moral et al. 2010; Romero et al. 2005). In addition, $N$. mediterraneum was the most virulent species from this study, although differences in virulence between tested isolates were observed. These differences were only observed when pathogenicity was evaluated on potted plants; they were not observed on detached branches. This result suggests that there is a possibility of finding genetic diversity within $N$. mediterraneum populations with geographic and host preferences. In fact, the teleomorph of $N$. mediterraneum was reported for the first time in the world in the Andalusian region (Moral et al. 2015), which invites us to further research its genetic diversity. In addition, studies conducted in Spain by Romero (2012), in which olive plants were inoculated with B. dothidea, Diplodia corticola, Dothiorella iberica, and $N$. mediterraneum, showed that only $N$. mediterraneum was able to induce cankers on plants with a high level of virulence. In other olivegrowing areas, a broad range of species belonging to the Botryosphaeriaceae family $(D$. mutila, $D$. seriata, $D$. iberica, $L$. theobromae, $N$. luteum, and $N$. parvum) has been associated with olive trees showing branch dieback (Sergeeva et al. 2009; Taylor et al. 2001; Úrbez-Torres et al. 2013).

Among all of the fungal taxa isolated from the symptomatic wood of olive in this study, Phoma-like species were the most diverse. All of the Tunisian isolates in this study were identified as Phoma-like species. In concordance with this result, today, only Phoma sp. and Phoma fungicola have been reported as causing branch dieback of olive trees in this country (Rhouma et al. 2010; Taieb et al. 2014). Our Tunisian isolates were identified as $N$. quercina and $C$. incompta but the latter was pathogenic to both detached branches and potted plants. In agreement with this result, $C$. incompta has also been described as causing branch dieback on olive in Croatia (Ivic et al. 2010), Greece (Malathrakis 1979), and Italy (Tosi and Natalini 2009; Tosi and Zazzerini 1994). Concerning negative pathogenicity results obtained for the $N$. quercina isolates (both Spanish and Tunisian), previous surveys on olive orchards in California revealed that the occurrence of Phoma spp. in olive is very low (Úrbez-Torres et al. 2013), leading us to hypothesize that it has limited pathogenicity in olive. It is well known that the Phoma genus contains plant-

Table 2. Susceptibility of olive cultivar inoculated with Neofusicoccum mediterraneum on detached branches and potted plants and Botryosphaeria dothidea on detached fruit ${ }^{\mathrm{w}}$

\begin{tabular}{|c|c|c|c|c|c|}
\hline \multirow[b]{3}{*}{ Cultivar } & \multicolumn{4}{|c|}{ Neofusicoccum mediterraneum } & \multirow{3}{*}{$\frac{\frac{\text { Botryosphaeria dothidea }}{\text { Fruit }}}{\text { AUDPC }^{z}}$} \\
\hline & \multicolumn{2}{|c|}{ Detached branches } & \multicolumn{2}{|c|}{ Potted plants } & \\
\hline & Canker (cm) & $\overline{\text { Pycnidia }(\mathbf{c m})^{x}}$ & Canker (cm) & $\overline{\operatorname{Dead}(\%)^{\mathrm{y}}}$ & \\
\hline Aloreña de Atarfe & - & - & $4.11 \mathrm{~b}$ & 0.00 & $1.70 \mathrm{a}$ \\
\hline Ascolana Tenera & $9.52 \mathrm{~cd}$ & $3.56 \mathrm{bc}$ & $\mathrm{n} / \mathrm{e}$ & $n / e$ & $\mathrm{n} / \mathrm{e}$ \\
\hline Gordal Sevillana & $15.72 \mathrm{a}$ & 3.03 bcde & $10.38 \mathrm{a}$ & 62.50 & $1.12 \mathrm{c}$ \\
\hline Hojiblanca & $11.22 \mathrm{bc}$ & 3.19 bcde & $3.43 \mathrm{~b}$ & 0.00 & $0.59 \mathrm{de}$ \\
\hline Manzanilla Cacereña & $6.19 \mathrm{e}$ & 2.74 cde & $10.60 \mathrm{a}$ & 83.33 & $0.82 \mathrm{~cd}$ \\
\hline Manzanilla de Sevilla & $12.38 \mathrm{~b}$ & $3.26 \mathrm{bcd}$ & $4.80 \mathrm{~b}$ & 16.67 & $1.54 \mathrm{ab}$ \\
\hline Morona & $7.64 \mathrm{de}$ & $2.23 \mathrm{e}^{4}$ & $5.25 \mathrm{~b}$ & 16.67 & $0.82 \mathrm{~cd}$ \\
\hline Ocal & $\mathrm{n} / \mathrm{e}$ & $\mathrm{n} / \mathrm{e}$ & $\mathrm{n} / \mathrm{e}$ & $\mathrm{n} / \mathrm{e}$ & $1.19 \mathrm{bc}$ \\
\hline San Agostino & $13.21 \mathrm{ab}$ & $5.38 \mathrm{a}$ & $\mathrm{n} / \mathrm{e}$ & $\mathrm{n} / \mathrm{e}$ & $0.29 \mathrm{e}$ \\
\hline Santa Caterina & $14.03 \mathrm{ab}$ & $3.63 \mathrm{~b}$ & $\mathrm{n} / \mathrm{e}$ & $\mathrm{n} / \mathrm{e}$ & $1.01 \mathrm{c}$ \\
\hline Verdial de Huévar & $6.32 \mathrm{e}$ & $2.24 \mathrm{de}$ & $3.06 \mathrm{~b}$ & 0.00 & $1.04 \mathrm{c}$ \\
\hline
\end{tabular}

${ }^{\mathrm{w}}$ Mean values with the same letter in a row are not significantly different according to Tukey's honestly significant difference test $(P<0.05) ;-$ indicates that no symptoms were observed and $\mathrm{n} / \mathrm{e}=$ cultivars not evaluated in each experiment.

$x$ Pycnidia colonization.

y Dead branches.

$\mathrm{z}$ Area under the disease progress curve.

Table 3. Morphological characteristics and mycelial growth of Colletotrichum, Cytospora, Diaporthe, Neofusicoccum, and Phoma-like isolates obtained from olive

\begin{tabular}{|c|c|c|c|c|c|c|c|}
\hline \multirow[b]{3}{*}{ Species } & \multirow[b]{3}{*}{ Isolate } & \multicolumn{6}{|c|}{ Mycelia } \\
\hline & & \multicolumn{3}{|c|}{ Obverse } & \multicolumn{2}{|c|}{ Reverse } & \multirow[b]{2}{*}{ Growthy } \\
\hline & & Color & Zonation & Margin & Color & Zonation & \\
\hline Colletotrichum godetiae & $\mathrm{CH}-21$ & Gray & No & Regular & Dark gray & No & 6.20 \\
\hline Cytospora sp. & $\mathrm{CH}-13$ & White & No & Irregular & White & No & 10.69 \\
\hline \multirow[t]{2}{*}{ Diaporthe sp. } & $\mathrm{CH}-01$ & White & Yes & Regular & White green & Yes & 12.86 \\
\hline & $\mathrm{CH}-03$ & White & Yes & Regular & White gray & Yes & 14.91 \\
\hline \multirow[t]{2}{*}{ Neofusicoccum mediterraneum } & $\mathrm{CH}-06$ & Light green & No & Regular & Gray Green & No & 17.84 \\
\hline & BOO071 & Olive green & No & Irregular & Olive green & No & 16.37 \\
\hline \multirow[t]{5}{*}{ Phoma-like } & $\mathrm{CH}-04$ & Brown yellow & Yes & Regular & Brown red & Yes & 3.30 \\
\hline & $\mathrm{CH}-12^{\mathrm{z}}$ & - & - & - & - & - & - \\
\hline & $\mathrm{CH}-14$ & White pink & No & Regular & Orange salmon & No & 7.95 \\
\hline & $\mathrm{CH}-15$ & White pink & No & Regular & Orange salmon & No & 9.28 \\
\hline & $\mathrm{CH}-16$ & Green yellow & No & Regular & Dark brown & No & 2.27 \\
\hline
\end{tabular}

${ }^{y}$ Growth (mm/day). Single conidial cultures were grown on potato dextrose agar for up to 2 weeks at $25 \pm 2^{\circ} \mathrm{C}$ with a 12 -h diurnal photoperiod of cool fluorescent light $\left(350 \mu \mathrm{mol} \mathrm{m}^{-2} \mathrm{~s}^{-1}\right)$.

${ }^{\mathrm{z}}$ Mycelia of this isolate was not optimum for development for its characterization. 
pathogenic species as well as numerous saprobic and endophytic species associated with a wide range of hosts (Chen et al. 2015).

Species in the genus Diaporthe were the third most prevalent fungi isolated in our study, with two isolates identified as Diaporthe spp. To date, species of this genus have only been associated with olive branch dieback in California (Úrbez-Torres et al. 2013). In our study, pathogenicity tests revealed that all isolates of Diaporthe were not pathogenic on olive branches. However, these results contrast with those obtained by Úrbez-Torres et al. (2013), who demonstrated the pathogenicity of some Diaporthe isolates on olive branches. Because species of Diaporthe are known to be cosmopolitan and found primarily as endophytes, parasites, and saprotrophs in a wide range of hosts (Udayanga et al. 2011), this difference in pathogenicity in olive between both countries could be due to variability in isolate virulence. Many other possible factors such as the age of the host or differences in cultivar susceptibility could also be explanatory. Thus, a broader pathogenicity study using a higher number of isolates of this genus and different plant cultivars will be required to further clarify the pathogenic role of Diaporthe spp. as causal agents of branch dieback on olive.

Cytospora pruinosa was isolated with the least prevalence. In addition, this was the least virulent species to detached branches among all the pathogenic fungi tested in this study, and was found to not be pathogenic to the potted plants. To our knowledge, this is the first report of $C$. pruinosa causing olive branch dieback in Spain. To date, only the species $C$. oleina has been associated with olive branch dieback in Greece (Rumbos 1988). Our results suggest that, although many fungi such as Diaporthe are pathogenic to a wide range of crops, they would only be able to induce cankers on hosts such as weakened or stressed olive trees. Notably, no relationship was found between the dead branches (percentage) of inoculated plants and canker length on detached branches. This reinforces the idea that inoculation in vivo is essential to the characterization of fungal pathogens or even to identify differences in virulence among isolates belonging to the same species. In addition, the nonpathogenic isolates were recovered from asymptomatic tissues, which indicates that they are common endophytic fungi in olive.

Pathogenicity of Colletotrichum godetiae, the main causal agent of olive anthracnose in Andalusia (Moral et al. 2014), was also evaluated on lignified tissues. This isolate was included to test the hypothesis that the syndrome of dead branches is caused by phytotoxins produced by this pathogen and often present in rotten fruit (Moral et al. 2009). The pathogenicity test showed that $C$. godetiae was not pathogenic to olive branches. The results support the idea that the isolates of the complex species $C$. acutatum do not cause the typical dieback symptoms through direct infection on lignified tissues, because the toxin produced by the pathogen is the main cause in inducing twig-branch dieback (Moral et al. 2009). However, a wide collection of Colletotrichum spp. should be tested for pathogenicity to elucidate the role of their toxins in branch dieback of olive.

Disease resistance of olive cultivars offer an economically sound alternative to chemical control, with minimal environmental impact, which can be integrated in pest management strategies. Here, we conducted the first comparison of cultivar resistance to $N$. mediterraneum causing cankers on olive worldwide, and to B. dothidea causing fruit rot of olive in Spain. Trials conducted on detached branches showed that 'Gordal Sevillana' was the cultivar most susceptible to

Table 4. Morphological characteristics of conidia and pycnidia of Colletotrichum, Cytospora, Diaporthe, Neofusicoccum and Phoma-like isolates obtained from olive

\begin{tabular}{|c|c|c|c|c|c|c|c|c|}
\hline \multirow[b]{2}{*}{ Species } & \multirow[b]{2}{*}{ Isolate } & \multicolumn{4}{|c|}{ Conidia } & \multicolumn{3}{|c|}{ Pycnidia } \\
\hline & & $\mathbf{L} \times \mathbf{W}(\boldsymbol{\mu m})^{\mathbf{v}}$ & $\mathbf{L} / \mathbf{W}$ & Morphology & Color & Morphology & Color & Diameter $(\mu \mathbf{m})$ \\
\hline $\begin{array}{l}\text { Colletotrichum } \\
\text { godetiae }\end{array}$ & $\mathrm{CH}-21^{\mathrm{w}}$ & $\begin{array}{c}(13.05-) 14.35(-15.65) \times \\
(4.03-) 4.59(-5.15)\end{array}$ & $3.17 \pm 0.48$ & $\begin{array}{l}\text { Aseptate, oblong- } \\
\text { fusiform and ligulated }\end{array}$ & Hyaline & - & - & - \\
\hline Cytospora sp. & $\mathrm{CH}-13$ & $\begin{array}{c}(4.92-) 5.47(-6.01) \times \\
(1.30-) 1.61(-1.92)\end{array}$ & $3.54 \pm 0.32$ & Aseptate, alantoide form & Hyaline & $\begin{array}{l}\text { Erumpent, ostiolate, } \\
\text { tuberculate, } \\
\text { globous and } \\
\text { velvety }\end{array}$ & Dark & $278.5-745.2$ \\
\hline \multirow[t]{4}{*}{ Diaporthe sp. } & $\mathrm{CH}-01^{\mathrm{x}}$ & $\begin{array}{r}(6.65-) 7.68(-8.71) \times \\
(1.78-) 2.21(-2.64)\end{array}$ & $3.60 \pm 0.83$ & $\begin{array}{l}\text { Oblong, slightly } \\
\text { fusiform and ligulated }\end{array}$ & Hyaline & $\begin{array}{l}\text { Ostiolate, globose, } \\
\text { erumpent and } \\
\text { velvety }\end{array}$ & Dark & $819.5-1241.1$ \\
\hline & & $(19.12-) 22.50(-25.88)$ & - & Filiform and curved & Hyaline & - & - & - \\
\hline & $\mathrm{CH}-03^{\mathrm{x}}$ & $\begin{array}{c}(5.27-) 6.26(-7.25) \times \\
(1.91-) 2.40(-2.89)\end{array}$ & $2.73 \pm 0.80$ & $\begin{array}{l}\text { Oblong, slightly } \\
\text { fusiform and ligulated }\end{array}$ & Hyaline & $\begin{array}{l}\text { Ostiolate, globose, } \\
\text { erumpent and } \\
\text { velvety }\end{array}$ & Dark & $654.5-1778.9$ \\
\hline & & $(9.30-) 16.80(-24.30)$ & - & Filiform and curved & Hyaline & - & - & - \\
\hline \multirow[t]{2}{*}{$\begin{array}{l}\text { Neofusicoccum } \\
\text { mediterraneum }\end{array}$} & $\mathrm{CH}-06$ & $\begin{array}{c}(16.30-) 20.18(-24.06) \times \\
(4.93-) 5.86(-6.79)\end{array}$ & $3.54 \pm 0.93$ & $\begin{array}{l}\text { Fusiform to oblong- } \\
\text { fusiform, } 0-2 \text { septa, } \\
\text { usual truncated base } \\
\text { and thin walled }\end{array}$ & Hyaline & $\begin{array}{l}\text { Ostiolate, globose, } \\
\text { erumpent and } \\
\text { velvety. }\end{array}$ & Dark & $401.9-1685.1$ \\
\hline & BOO071 & $\begin{array}{c}(23.27-) \\
\quad 25.77(-28.27) \times \\
(6.37-) 7.35(-8.33)\end{array}$ & $3.57 \pm 0.60$ & Aseptate and fusiform & Hyaline & $\begin{array}{l}\text { Ostiolate, globose, } \\
\text { erumpent, with } \\
\text { conidia in cirrus }\end{array}$ & Dark & $431.2-1465.3$ \\
\hline \multirow[t]{5}{*}{ Phoma-like } & $\mathrm{CH}-04 \mathrm{y}$ & $\begin{array}{r}(4.22-) 4.93(-5.64) \times \\
(3.17-) 2.70(-3.17)\end{array}$ & $1.87 \pm 0.47$ & $\begin{array}{l}\text { Soft texture ellipsoid or } \\
\text { ovoid, slightly } \\
\text { flattened and thin- } \\
\text { walled }\end{array}$ & Dark & $\begin{array}{l}\text { Branched, wooded, } \\
\text { velvety, sprawled }\end{array}$ & Dark & - \\
\hline & $\mathrm{CH}-12$ & $\begin{array}{r}(2.65-) 3.0(-3.35) \times \\
(0.92-) 1.17(-1.42)\end{array}$ & $2.66 \pm 0.56$ & $\begin{array}{l}\text { Aseptate, oblong to } \\
\text { oblong-fusiform }\end{array}$ & Hyaline & Ostiolate, globose & Dark & $60.7-168.5$ \\
\hline & $\mathrm{CH}-14$ & $\begin{array}{r}(4.23-) 4.69(-5.15) \times \\
(1.15-) 1.78(-2.06)\end{array}$ & $2.69 \pm 0.48$ & $\begin{array}{l}\text { Aseptate, oblong and } \\
\text { thin-walled }\end{array}$ & Hyaline & Ostiolate, globose & Dark & $26.1-142.1$ \\
\hline & $\mathrm{CH}-15^{\mathrm{z}}$ & - & - & - & - & Ostiolate, globose & Dark & $22.8-73.8$ \\
\hline & $\mathrm{CH}-16$ & $\begin{array}{c}(2.73-) 3.20(-3.67) \times \\
(0.71-) 0.83(-0.95)\end{array}$ & $2.01 \pm 0.25$ & Aseptate and oblong & Hyaline & Ostiolate, globose & Dark & $27.7-83.8$ \\
\hline
\end{tabular}

\footnotetext{
${ }^{v}$ Mean and range values: length $(\mathrm{L})$ by width $(\mathrm{W})(\mu \mathrm{m})$. Extremes of the conidial measurements are shown inside parenthesis.

${ }^{w}$ This isolate produces conidia in acervuli instead of in pycnidia.

${ }^{x}$ Isolates with both conidia types ( $\alpha$ and $\beta$ ).

y Isolate with irregular pycnidia.

${ }^{\mathrm{z}}$ Conidia were not observed for this isolate.
} 
N. mediterraneum, followed by 'Santa Caterina' and 'San Agostino', whereas 'Manzanilla Cacereña' was the most resistant, followed by 'Verdial de Huévar' and 'Morona'. Detached branches could be under great stress and does not behave physiologically in the same way as a branch attached to a tree. Thus, results obtained from detached branches could not be absolutely representative of cultivar resistance. In this way, cultivar resistance was also evaluated by using potted plants. In this case, inverted results than those obtained by using

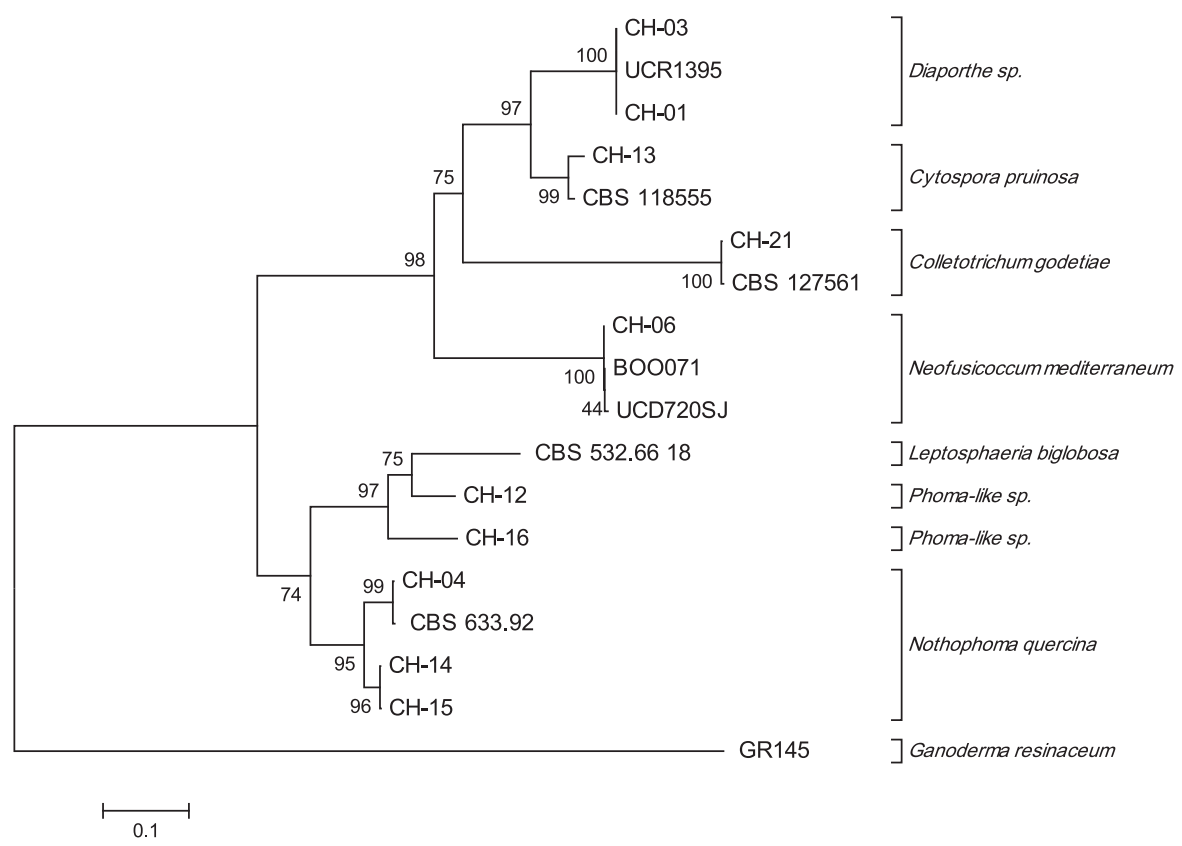

Fig. 2. Phylogenetic analysis of taxa for the combined alignment of internal transcribed spacer and $\beta$-tubulin sequences. The evolutionary history was inferred using the neighbor-joining method (Saitou and Nei 1987). The optimal tree with the sum of branch length $=2.64571884$ is shown. The percentage of replicate trees in which the associated taxa clustered together in the bootstrap test (2,000 replicates) are shown next to the branches (Felsenstein 1985). The tree is drawn to scale, with branch lengths in the same units as those of the evolutionary distances used to infer the phylogenetic tree. The evolutionary distances were computed using the Kimura two-parameter method (Kimura 1980) and are in the units of the number of base substitutions per site. The rate variation among sites was modeled with a $\gamma$ distribution (shape parameter $=1$ ). The analysis involved 18 nucleotide sequences. All positions containing gaps and missing data were eliminated. There were a total of 667 positions in the final data set. Evolutionary analyses were conducted in MEGA6 (Tamura et al. 2013 ).
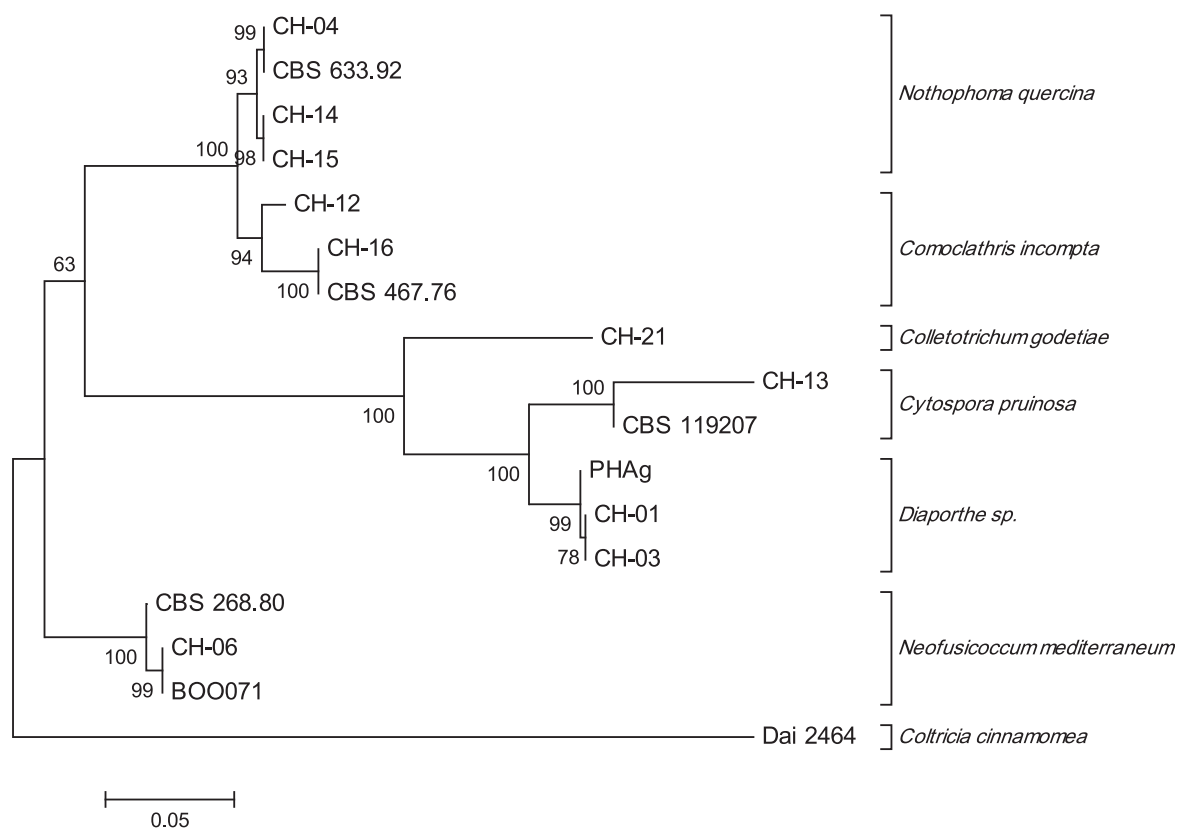

Fig. 3. Phylogenetic analysis of taxa for large subunit nuclear ribosomal DNA sequences. The evolutionary history was inferred using the neighbor-joining method (Saitou and Nei 1987). The optimal tree with the sum of branch length $=0.82306726$ is shown. The percentage of replicate trees in which the associated taxa clustered together in the bootstrap test (2,000 replicates) are shown next to the branches (Felsenstein 1985). The tree is drawn to scale, with branch lengths in the same units as those of the evolutionary distances used to infer the phylogenetic tree. The evolutionary distances were computed using the Kimura two-parameter method (Kimura 1980) and are in the units of the number of base substitutions per site. The rate variation among sites was modeled with a $\gamma$ distribution (shape parameter $=1$ ). The analysis involved 17 nucleotide sequences. All positions containing gaps and missing data were eliminated. There were a total of 782 positions in the final data set. Evolutionary analyses were conducted in MEGA6 (Tamura et al. 2013). 


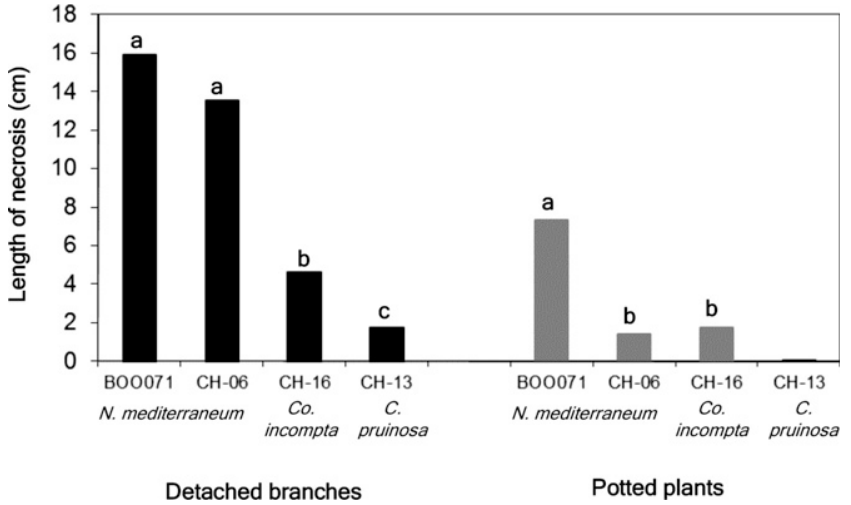

Fig. 4. Disease severity on detached branches and olive plants (Gordal Sevillana) 2 weeks and 1 month, respectively, after inoculation with Neofusicoccum mediterraneum isolates $\mathrm{BOO} 071$ and $\mathrm{CH}-06$, Cytospora sp. isolate $\mathrm{CH}-13$, and Comoclathris incompta isolate $\mathrm{CH}-16$. For each isolate, mean values with the same letter are not significantly different according to Tukey's honestly significant difference test $(P<0.05)$.

detached branches were observed on potted plants, where 'Manzanilla Cacereña' was the most susceptible cultivar to $N$. mediterraneum, followed by 'Gordal Sevillana'. 'Verdial de Huévar' was the most resistant cultivar. The last results are in concordance with those obtained by Romero (2012), who indicated that 'Gordal Sevillana' was more susceptible than 'Picual' when live plants were inoculated with $N$. mediterraneum. Concerning $B$. dothidea, results revealed that 'Aloreña de Atarfe' was the most susceptible cultivar, whereas 'Hojiblanca' and 'San Agostino' were the most resistant. These results complement those obtained by Latinović et al. (2013), who described highly resistant native 'Crnjaka' and 'Gloginja' olive. It is interesting to note that the resistance of green olive fruit to $B$. dothidea is not correlated with the resistance of ripe fruit to $C$. godetiae, showing that different resistance mechanisms are at work in both types of fruit (Moral et al. 2014).

Cultivar resistance to Botryosphaeriaceae species affecting lignified tissues of perennial crops has also been studied in mango (Mangifera indica $\mathrm{L}$ ) and pistachio (Pistachio vera L.) (Parfitt et al. 2003). According to our results, 'Spanish Hojiblanca', 'Manzanilla Cacereña', and 'Verdial de Huévar' olive showed a good level of resistance to branch dieback, making cultivar resistance a potential alternative tool against both branch dieback types.

This study has resulted in significant information regarding the etiology of branch dieback of olive as well as cultivar resistance to $N$. mediterraneum and $B$. dothidea. The variation found among fungal species recovered from affected olive trees with cankers and branch dieback symptoms should be taken into account to develop optimum control strategies. Therefore, further research is needed to elucidate the role of many fungal species associated with branch dieback of olive, as well as the environmental and cultural practices that influence the disease.

\section{Acknowledgments}

This research was funded by the Spanish Ministry of Education and Science (project AGL2004-7495) and by the Andalusian Regional Government (Project P08-AGR-03635). Both projects were co-financed by the European Union FEDER Funds. J. Moral holds a Marie Skłodowska Curie fellowship launched by the European Union's H2020 (contract number 658579). C. Agustí-Brisach is the holder of a "Juan de la Cierva-Formación" fellowship from MINECO. We thank J. A. Layosa and F. Luque for skillful technical assistance; and C. Cunningham, $\mathrm{K}$. Tomari, and T. J. Michailides for critical review of the manuscript.

\section{Literature Cited}

Barnett, H. L., and Hunter, B. B. 1998. Illustrated genera of imperfect fungi, 4th ed. American Phytopathological Society, St. Paul, MN.

Barranco, D., Fernández-Escobar, R., and Rallo, L., eds. 2008. El cultivo de olivo. Junta de Andalucía \& Mundi-Prensa, Madrid.

Barranco, D., and Rallo, L. 2000. Olive cultivars in Spain. HortTechnology 10: 107-110.

Carbone, I., Anderson, J. B., and Kohn, L. M. 1999. A method for designing primer sets for the speciation studies in filamentous ascomycetes. Mycologia 91:553-556.

Carlucci, A., Lops, F., Cibelli, F., and Raimondo, M. L. 2015. Phaeoacremonium species associated with olive wilt and decline in southern Italy. Eur. J. Plant Pathol. 141:717-729.
Carlucci, A., Raimondo, M. L., Cibelli, F., Phillips, J. L., and Lops, F. 2013. Pleurostomophora richardsiae, Neofusicoccum parvum and Phaeoacremonium aleophilum associated with a decline of olives in southern Italy. Phytopathol. Mediterr. 52:517-527.

Chen, Q., Jiang, J. R., Zhang, G. Z., Cai, L., and Crous, P. W. 2015. Resolving the Phoma enigma. Stud. Mycol. 82:137-217.

Crous, P. W., Wingfield, M. J., Guarro, J., Hernández-Restrepo, M., Sutton, D. A., Acharya, K., Barber, P. A., Boekhout, T., Dimitrov, R. A., Dueñas, M., Dutta, A. K., Gené, J., Gouliamova, D. E., Groenewald, M., Lombard, L., Morozova, O. V., Sarkar, J., Smith, M. Th., Stchigel, A. M., Wiederhold, N. P., Alexandrova, A. P., Antelmi, I., Armengol, J., Barnes, I., Cano-Lira, J. F., Castañeda Ruiz, R. F., Contu, M., Courtecuisse, Pr. R., da Silveira, A. L., Decock, C. A., de Goes, A., Edathodu, J., Ercole, E., Firmino, A. C., Fourie, A., Fournier, J., Furtado, E. L., Geering, A. D. W., Gershenzon, J., Giraldo, A., Gramaje, D., Hammerbacher, A., He, X.-L., Haryadi, D., Khemmuk, W., Kovalenko, A. E., Krawczynski, R., Laich, F., Lechat, C., Lopes, U. P., Madrid, H., Malysheva, E. F., Marín-Felix, Y., Martín, M. P., Mostert, L., Nigro, F., Pereira, O. L., Picillo, B., Pinho, D. B., Popov, E. S., Rodas Peláez, C. A., Rooney-Latham, S., Sandoval-Denis, M., Shivas, R. G., Silva, V., StoilovaDisheva, M. M., Telleria, M. T., Ullah, C., Unsicker, S. B., van der Merwe N. A., Vizzini, A., Wagner, H.-G., Wong, P. T. W., Wood, A. R., and Groenewald, J. Z. 2015. Fungal Planet description sheets: 320-370. Persoonia 34:167-266.

Dhingra, O. D., and Sinclair, J. B. 1995. Basic Plant Pathology Methods, 2nd Ed. CRC Press, Boca Raton, FL.

Eldesouki, I. E. 2013. Interacciones de Batrocera oleae Gmel. (Mosca del olivo) con Botryosphaeria dothidea Moug. (Escudete de la aceituna) y de Phloeotribus scarabaeoides Bern. (Barrenillo del olivo) con Verticillium dahliae Kleb. causante de la Verticilosis del olivo. Ph.D. thesis, University of Córdoba, Córdoba, Spain.

Felsenstein, J. 1985. Confidence limits on phylogenies: An approach using the bootstrap. Evolution 39:783-791.

Glass, N., and Donaldson, G. C. 1995. Development of primer sets designed for use with the PCR to amplify conserved genes from filamentous Ascomycetes. Appl. Environ. Microbiol. 61:1323-1330.

Iannotta, N., Noce, M. E., Ripa, V., Scalercio, S., and Vizzarri, V. 2007. Assessment of susceptibility of olive cultivars to the Bactrocera oleae (Gmelin, 1790) and Camarosporium dalmaticum (Thüm) Zachos \& Tzav.-Klon. attacks in Calabria (Southern Italy). J. Environ. Sci. Health 42:789-793.

Ivic, D., Ivanovic, A., Milicevic, T., and Cvjetkovic, B. 2010. Shoot necrosis of olive caused by Phoma incompta, a new disease of olive in Croatia. Phytopathol. Mediterr. 49:414-416.

Kimura, M. 1980. A simple method for estimating evolutionary rate of base substitutions through comparative studies of nucleotide sequences. J. Mol Evol. 16:111-120.

Kornerup, A., and Wanscher, J. H. 1963. Methuen Handbook of Colour. Methuen and Co. Ltd., London.

Larkin, M. A., Blackshields, G., Brown, N. P., Chenna, R., McGettigan, P. A., McWilliam, H., Valentin, F., Wallace, I. M., Wilm, A., López, R., Thompson, J. D., Gibson, T. J., and Higgins, D. G. 2007. Clustal Wand Clustal X version 2.0. Bioinformatics 23:2947-2948.

Latinović, J., Mazzaglia, A., Latinović, N., Ivanović, M., and Gleason, M. L. 2013. Resistance of olive cultivars to Botryosphaeria dothidea, causal agent of olive fruit rot in Montenegro. Crop Prot. 48:35-40.

Lazzizera, C., Frisullo, S., Alves, A., Lopes, J., and Phillips, A. J. L. 2008a Phylogeny and morphology of Diplodia species on olives in southern Italy and description of Diplodia olivarum sp. nov. Fungal Divers. 31:63-71.

Lazzizera, C., Frisullo, S., Alves, A., and Phillips, A. J. L. 2008b. Morphology, phylogeny and pathogenicity of Botryosphaeria and Neofusicoccum species associated with drupe rot of olives in southern Italy. Plant Pathol. 57:948-956.

Liu, J. K., Hyde, K. D., Jones, E. B. G., Ariyawansa, H. A., Bhat, D. J., Boonmee, S., Maharachchikumbura, S. S. N., McKenzie, E. H. C., Phookamsak, R., Phukhamsakda, C., Shenoy, B. D., Abdel-Wahab, M. A., Buyck, B., Chen, J., Chethana, K. W. T., Singtripop, C., Dai, D. Q., Dai, Y. C., Daranagama, D. A., Dissanayake, A. J., Doilom, M., D'souza, M. J., Fan, X. L., Goonasekara, I. D., Hirayama, K., Hongsanan, S., Jayasiri, S. C., Jayawardena, R. S., Karunarathna, S. C., Li, W. J., Mapook, A., Norphanphoun, C., Pang, K. L., Perera, R. H., Peršoh, D., Pinruan, U., Senanayake, I. C., Somrithipol, S., Suetrong, S., Tanaka, K., Thambugala, K. M., Tian, Q., Tibpromma, S., Udayanga, D., Wijayawardene, N. N., Wanasinghe, D. N., Wisitrassameewong, K., Zeng, X. Y., Abdel-Aziz, F. A., Adamč́́k, S., Bahkali, A. H., Boonyuen, N., Bulgakov, T., Callac, P., Chomnunti, P., Greiner, K., Hashimoto, A., Hofstetter, V., Kang, J. C., Lewis, D., Li, X. H., Liu, X. Z., Liu, Z. Y., Matsumura, M., Mortimer, P. E., Rambold, G., Randrianjohany, E., Sato, G., Sri-Indrasutdhi, V., Tian, C. M., Verbeken, A., Von Brackel, W., Wang, Y., Wen, T. C., Xu, J. C., Yan, J. Y., Zhao, R. L., and Camporesi, E. 2015. Fungal diversity notes 1-110: Taxonomic and phylogenetic contributions to fungal species. Fungal Divers. 72:1-197.

MAGRAMA. 2016. Superficie y producción. Online publication. Ministerio de Agricultura, Alimentación y Medio Ambiente. http://www.magrama.gob.es/es/ agricultura/temas/producciones-agricolas/aceite-oliva-y-aceituna-mesa/aceituna. aspx\#para2

Malathrakis, N. E. 1979. Studies on a disease of olive due to fungus Phoma incompta Sacc. \& Mart. Ph.D. thesis, University of Athens, Athens. 
Moral, J., Bouhmidi, K., and Trapero, A. 2008a. Influence of fruit maturity, cultivar susceptibility, and inoculation method on infection of olive fruit by Colletotrichum acutatum. Plant Dis. 92:1421-1426.

Moral, J., De Oliveira, R., and Trapero, A. 2009. Elucidation of the disease cycle of olive anthracnose caused by Colletotrichum acutatum. Phytopathology 99:548-556.

Moral, J., Eldesouki-Arafat, I., López-Escudero, F. J., Vargas-Osuna, E., Trapero, A., and Aldebis, H. K. Olive escudete, caused by Botryosphaeria dothidea, as result of the interaction fly-mosquito-fungus. Phytopathology In press.

Moral, J., Luque, F., and Trapero, A. 2008b. First report of Diplodia seriata, the anamorph of "Botryosphaeria" obtusa, causing fruit rot of olive in Spain. Plant Dis. 92:311.

Moral, J., Muñoz-Díez, C., González, N., Trapero, A., and Michailides, T. J. 2010. Characterization and pathogenicity of Botryosphaeriaceae species collected from olive and other hosts in Spain and California. Phytopathology 100:1340-1351.

Moral, J., Pérez-Rodríguez, M., Michailides, T. J., and Trapero, A. 2015. First report of the teleomorph of Neofusicoccum mediterraneum, a pathogen of olive. Phytopathology 105:S97.

Moral, J., Xaviér, C., Roca, L. F., Romero, J., Moreda, W., and Trapero, A. 2014. La Antracnosis del olivo y su efecto en la calidad del aceite. Grasas Aceites 65:e028.

Parfitt, D. E., Arjmand, N., and Michailides, T. J. 2003. Resistance to Botryosphaeria dothidea in pistachio. HortScience 38:529-531.

Phillips, A. J. L., Alves, A., Abdollahzadeh, J., Slippers, B., Wingfield, M. J., Groenewald, J. Z., and Crous, P. W. 2013. The Botryosphaeriaceae: Genera and species known from culture. Stud. Mycol. 76:51-167.

Rallo, L., Barranco, D., Caballero, J. M., Del Río, C., Martín, A., Tous, J., and Trujillo, I., eds. 2005. Las variedades de olivo cultivadas en España. Consejería de Agricultura y Pesca, Ministerio de Agricultura, Pesca y Alimentación and Ediciones Mundi-Prensa, Madrid.

Rehner, S. A., and Samuels, G. J. 1994. Taxonomy and phylogeny of Gliocladium analysed from nuclear large subunit ribosomal DNA sequences. Mycol. Res. 98:625-634.

Rhouma, A., Triki, M. A., Krid, S., and Masallem, M. 2010. First report of a branch dieback of olive trees in Tunisia caused by a Phoma sp. Plant Dis. 94:636.

Romero, M. A. 2012. Etiología, epidemiología y control del chancro de los Quercus causado por Botryosphaeria spp. Ph.D. thesis, University of Cordoba, Cordoba, Spain.

Romero, M. A., Sánchez, M. E., and Trapero, A. 2005. First report of Botryosphaeria ribis as a branch dieback pathogen of olive trees in Spain. Plant Dis. 89:208.

Rumbos, I. C. 1988. Cytospora oleina causing canker and dieback of olive in Greece. Plant Pathol. 37:441-444.

Rumbos, I. C. 1993. Dieback symptoms on olive trees caused by the fungus Eutypa lata. Bull. OEPP/EPPO Bull. 23:441-445.
Saitou, N., and Nei, M. 1987. The neighbor-joining method: A new method for reconstructing phylogenetic trees. Mol. Biol. Evol. 4:406-425.

Sergeeva, V., Alves, A., and Phillips, A. J. L. 2009. Neofusicoccum luteum associated with leaf necrosis and fruit rot of olives in New South Wales, Australia. Phytopathol. Mediterr. 48:294-298.

Sutton, B. C. 1980. The Coelomycetes. Fungi Imperfecti with Pycnidia, Acervuli and Stromata. Commonwealth Mycological Institute, Kew, UK.

Taieb, S. K. H., Triki, M. A., Hammami, I., and Rhouma, A. 2014. First report of dieback of olive trees caused by Phoma fungicola in Tunisia. J. Plant Pathol. 96: 117

Tamura, K., Stecher, G., Peterson, D., Filipski, A., and Kumar, S. 2013. MEGA6: Molecular Evolutionary Genetics Analysis version 6.0. Mol. Biol. Evol. 30: $2725-2729$

Taylor, R. K., Hale, C. N., and Hartill, W. F. T. 2001. A stem canker disease of olive (Olea europaea) in New Zealand. N. Z. J. Crop Hortic. Sci. 29:219-228.

Tosi, L., and Natalini, G. 2009. First report of Eutypa lata causing dieback of olive trees in Italy. Plant Pathol. 58:398.

Tosi, L., and Zazzerini, A. 1994. Phoma incompta a new olive parasite in Italy. Petria 4:161-170.

Udayanga, D., Xingzhong, L., McKenzie, E. H. C., Chukeatirote, E., Bahkali, A. H. A., and Hyde, K. D. 2011. The genus Phomopsis: Biology, applications, species concepts and names of common phytopathogens. Fungal Divers. 50: $189-225$.

Úrbez-Torres, J. R., Peduto, F., Vossen, P. M., Krueger, W. H., and Gubler, W. D. 2013. Olive twig and branch dieback: Etiology, incidence, and distribution in California. Plant Dis. 97:231-244.

van Niekerk, J. M., Crous, P. W., Groenewald, J. Z., Fourie, P. H., and Halleen, F. 2004. DNA phylogeny, morphology and pathogenicity of Botryosphaeria species on grapevines. Mycologia 96:781-798

Vilgalys, R., and Hester, M. 1990. Rapid genetic identification and mapping of enzymatically amplified ribosomal DNA from several Cryptococcus species. J. Bacteriol. 172:4238-4246.

White, T. J., Bruns, T., Lee, S., and Taylor, J. 1990. Amplification and direct sequencing of fungi ribosomal RNA genes for phylogenetics. Pages 315-322 in: PCR Protocols. A Guide to Methods and Applications. M. A Innis, D. H. Gelfand, J. J. Sninsky, and T. J. White, eds. Academic Press, San Diego, CA.

Zachos, D. G., and Tzavella-Klonari, K. 1983. Recherches sur les causes des infections localisées ou géneéralisées des olives attaquées par le champignon Camarosporium dalmatica. I. Influence de l'humidité, de la pression osmotique et du $\mathrm{pH}$ des fruits. Ann. Inst. Phytopathol. Benaki 14:1-9. 